Original Research Paper

\title{
Endoscopic Changes of Nasal Mucosa in Patients with Leprosy
}

\author{
${ }^{1}$ Carla Andrea Avelar Pires, ${ }^{2}$ Eline Pinheiro Weba Costa, ${ }^{3}$ Marcus Vinicius Duarte Costa, \\ ${ }^{4}$ Adriana Kamilly Leitão Pitman Machado, ${ }^{5}$ Aline de Lima Dias, ${ }^{6}$ Gabriela Athayde Amin, ${ }^{6}$ Manuela \\ ${ }^{1}$ Department of Dermatology, Universidade do Estado do Pará, Belém, Pará, Brazil \\ ${ }^{2}$ Department of Otolaryngology, \\ Hospital Universitário Bettina Ferro, Universidade Federal do Pará, Belém, Pará, Brazil \\ ${ }^{3}$ Department of Dermatology, Centro Universitário do Estado do Pará, Belém, Pará, Brazil \\ ${ }^{4}$ Department of Dermatology, \\ Centro Universitário do Estado do Pará; Universidade do Estado do Pará, Belém, Pará, Brazil \\ ${ }^{5}$ Núcleo de Medicina Tropical, Universidade Federal do Pará, Belém, Pará, Brazil \\ ${ }^{6}$ Universidade Federal do Pará, Belém, Pará, Brazil
} Nascimento de Lemos, ${ }^{5}$ Alison Ramos da Silva, ${ }^{6}$ Marcos Antonio Neves Noronha and ${ }^{5}$ Marilia Brasil Xavier

\section{Article history}

Received: 09-03-2019

Revised: 22-04-2019

Accepted: 02-05-2019

Corresponding Author: Carla Andrea Avelar Pires Department of Dermatology, Universidade do Estado do Pará, Belém, Pará, Brazil Email: carlaavelarpires@gmail.com

\begin{abstract}
Leprosy is a chronic granulomatous disease, affecting the skin and Schwann cells of peripheral nerves. In most leprosy cases, the nasal mucosa is affected. We aimed to describe the clinical changes in nasal mucosa using nasal endoscopy, in patients with leprosy attending a dermatology service in an endemic region and compare this changes with those founds in non-leprosy patients nasal mucosa. This crosssectional study examined and compared 16 leprosy patients and 16 non-leprosy patients. Nasal endoscopy was conducted in both groups to determine differences between the two groups and analysis was applied to evaluate factors related to changes in the nasal mucosa. A larger number of changes in the nasal mucosa was observed in multibacillary patients $(75 \%)$; infiltration, lepromas and hematic crusts were the changes that were most commonly observed. There was a larger proportion of men $(68.8 \%)$ diagnosed as having leprosy; they demonstrated a 23-fold increase of nasal mucosa involvement compared to women. There was no positive correlation between nasal symptoms and changes observed in the nasal mucosa. Therefore, it is important to perform an otorhinolaryngological examination and, more importantly, an endoscopic examination of the nasal mucosa, regardless of the presence or absence of symptoms or the clinical presentation of patients with leprosy.
\end{abstract}

Keywords: Leprosy, Nasal Mucosa, Nasal Endoscopy

\section{Introduction}

Leprosy is a chronic infectious disease, caused by Mycobacterium leprae, affecting the skin and peripheral nerves, thereby resulting in cutaneous lesions and neuropathy (Oliveira et al., 2013; Queiroz et al., 2015). It is characterized by dermatological and neurological signs and symptoms, which range from hypochromic spots with irregular borders, to hypoesthesia and diffuse and progressive infiltration of the skin. Mucous membranes may be affected, how eyes, lymph nodes and upper airways (Lastória and Abreu, 2014). The neurological manifestation includes the appearance of lesions occurring mainly in peripheral nerves, which is related to sensorial loss, physical disabilities and deformities (Budel et al., 2011; Lopes et al., 2017). The World Health Organization classifies leprosy as paucibacillary and multibacillary; the latter causes physical disfigurement and disability in severe cases (Gashignard et al., 2016; Lopes et al., 2017). In the early
C 2019 Carla Andrea Avelar Pires, Eline Pinheiro Weba Costa, Marcus Vinicius Duarte Costa, Adriana Kamilly, Leitão Pitman Machado Aline de Lima Dias, Gabriela Athayde Amin, Manuela Nascimento de Lemos, Alison Ramos da Silva, Marcos Antonio Neves Noron. This open access article is distributed under a Creative Commons Attribution (CC-BY) 3.0 
stages of $M$. leprae infection, the nasal mucosa is primarily affected, with the upper airway being the main form of transmission to untreated patients (Silva et al., 2008). The nasal manifestation of the disease involves tuberous eruption of the skin invading the nasal mucosa, mouth, throat, larynx and eyes (Martins et al., 2005).At nasal mucosa, there are common complications as hyposmia, nasal obstruction, epistaxis, crusts and rhinorrhea (Sun et al., 2018).

In recently diagnosed cases, the nasal mucosa of leprosy patients is affected (Silva et al., 2008). Despite this, only few studies have investigated the profile of these changes or how these nasal changes manifest clinically. The aim of this study was to describe endoscopic changes in nasal mucosal of patients with leprosy.

\section{Materials and Methods}

A cross-sectional study was carried out, involving 16 leprosy patients attending the dermatology outpatient clinic at the State University of Pará (UEPA). These 16 patients were screened for changes to the nasal mucosa and were classified as follows: 8 as paucibacillary and 8 as multibacillary. The control group comprised 16 patients previously diagnosed as having psoriasis, an inflammatory dermatological disease that does not involve the nasal mucosa and was selected as a suitable control sample group for this reason.

The study group comprised of both male and female patients diagnosed as having leprosy and the patients were over 18 years of age. Patients with underlying otolaryngological diseases were excluded. The control group included male and female patients, who were over 18 years of age and presented with a previous clinical and histopathological diagnosis of psoriasis without any symptoms or signs of leprae, clinically or histopathologically. The research was undertaken between May and December 2015.

Inclusion criteria to the study for the leprosy group was as follows: An individual presenting with one or more of the following signs: (1) A lesion and/or skin area with change in sensation; (2) involvement of the peripheral nerve, with or without thickening, associated with sensitivity and/or motor and/or autonomous changes and; (3) positive bacilloscopy, confirmed by obtaining an intradermal swab sample (MSB, 2010). The patients were classified using the Madrid clinical classification (Quagliato, 1999), which takes into consideration both clinical and bacilloscopic aspects of the disease.

Clinical examination consisted of a morphological assessment, including a count of the number and location of the lesions identified. The neurological evaluation consisted of inspection, palpation and percussion tests, in addition to strength and sensation tests. During the examination of the nasal cavity, the presence of secretions, bleeding, ulcers and crusts was observed and noted.
Socio-demographic data (gender, age, ethnicity, education, country of origin), clinical data (clinical form, operational classification, disease duration, presence of reactional state and comorbidities) and specific variables regarding the nasal mucosa (nasal mucosa characteristics, existence and type of secretion, presence or absence of vegetative lesions and ulcers) was collected.

Nasal endoscopy was conducted using optic fiber instrumentation coupled to a micro camera (Olympus). Lidocaine $2 \%$ spray was applied to the nasal fossa, to administer local anesthesia. An optic fiber, ranging between 3-4 $\mathrm{mm}$ in thickness, was introduced into the nasal region. The images were assessed by two otolaryngologists. In the event of disagreement, a third otolaryngologist made a determining assessment. It is important to emphasize that our aim was to describe macroscopic lesions, so, we have not made biopsy of nasal mucosa in any patient.

The data was subjected to descriptive analysis to obtain the absolute and relative frequencies, measures of central tendency (mean) and variability (standard deviation). An association between each independent and dependent variable was confirmed and obtained by applying the chi-square test, Fisher's exact test, or the Gtest. To analyze the factors associated with changes in nasal mucosa, logistic regression analysis was performed. The statistical analyses were processed using Stata 12.0 software (StataCorp). The level of significance of the findings was fixed by the alpha lower than $5 \%$.

The study was approved by the local Research Ethics Committee (Report Number: 945.972).

\section{Results}

When considering the socio-demographic profile, a significant difference was observed between the two groups regarding educational qualifications $(\mathrm{p}<0.05)$. The control group had attained a more advanced level of education. No such trend was observed in the study group with leprosy (Table 1).

Signs and symptoms of olfactory changes were mostly absent in both groups, despite noting a number of changes to the nasal mucosa in $43.8 \%$ of leprosy patients (Table 2). With consideration to the operational classification of leprosy patients, the number of changes in the nasal mucosa was significantly higher in the multibacillary form (Table 3). When assessing neurological responses, we noted that all patients with mucosa alterations also demonstrated leprosy-related neurological responses (Table 4).

When both the leprosy subjects and the control subjects were simultaneously assessed, $90 \%$ of individuals presenting with changes to the nasal mucosa were shown to be males (Table 5). Among the otorhinolaryngological symptoms, rhinorrhea is 
frequently present and accounts for $30 \%$ of individuals with changes to the mucosa (Table 6).

The alterations caused by leprosy were significantly higher in multibacillary patients (Table 7). Endoscopic examination of the nasal mucosa showed heterogeneous changes to the inferior and middle nasal conchae, as well as to the nasal septum of leprosy patients. The only changes to the control group were seen in the inferior nasal concha and nasal septum (Table 8).

Table 1: Observation groups according to variables of demographic characterization

\begin{tabular}{|c|c|c|c|c|c|c|c|}
\hline \multirow[b]{3}{*}{ Variables } & \multicolumn{6}{|c|}{ Observation groups } & \multirow[b]{3}{*}{$\mathrm{p}$-value } \\
\hline & \multicolumn{2}{|c|}{ Psoriasis } & \multicolumn{2}{|c|}{ Leprosy } & \multicolumn{2}{|c|}{ Total } & \\
\hline & $\mathrm{n}$ & $\%$ & $\mathrm{~N}$ & $\%$ & $\mathrm{n}$ & $\%$ & \\
\hline \multicolumn{8}{|l|}{ Gender } \\
\hline Female & 8 & 50.0 & 5 & 31.2 & 13 & 40.6 & $0.472^{¥}$ \\
\hline Male & 8 & 50.0 & 11 & 68.8 & 19 & 59.4 & \\
\hline \multicolumn{8}{|l|}{ Age group (years) } \\
\hline$\leq 30$ & 2 & 12.5 & 3 & 18.8 & 5 & 15.6 & $0.183^{\#}$ \\
\hline 31 to 45 & 2 & 12.5 & 6 & 37.5 & 8 & 25.0 & \\
\hline 46 to 60 & 7 & 43.8 & 6 & 37.5 & 13 & 40.6 & \\
\hline$>60$ & 5 & 31.2 & 1 & 6.2 & 6 & 18.8 & \\
\hline \multicolumn{8}{|l|}{ Procedência } \\
\hline Metropolitan region & 15 & 93.8 & 12 & 75.0 & 27 & 84.4 & $0.333^{*}$ \\
\hline Interior of State & 1 & 6.2 & 4 & 25.0 & 5 & 15.6 & \\
\hline \multicolumn{8}{|l|}{ Instruction } \\
\hline Illiterate & 1 & 6.2 & 2 & 12.5 & 3 & 9.4 & $0.007^{\#}$ \\
\hline Elementary School (incomplete) & 3 & 18.8 & 7 & 43.8 & 10 & 31.2 & \\
\hline Elementary School (complete) & 1 & 6.2 & 3 & 18.8 & 4 & 12.5 & \\
\hline Secondary School (incomplete) & - & - & 3 & 18.8 & 3 & 9.4 & \\
\hline Secondary School (complete) & 5 & 31.2 & - & - & 5 & 15.6 & \\
\hline Graduation (complete or incomplete) & 6 & 37.5 & 1 & 6.2 & 7 & 21.9 & \\
\hline Total & 16 & 100.0 & 16 & 100.0 & 32 & 100.0 & --- \\
\hline
\end{tabular}

${ }^{¥}$ Chi-square Test *Fisher’s Exact Test. ${ }^{\#} \mathrm{G}$ Test

Table 2: Observation groups according to variables of otorhinolaryngological symptomatology

\begin{tabular}{|c|c|c|c|c|c|c|c|}
\hline \multirow[b]{3}{*}{ Varaibles } & \multicolumn{6}{|c|}{ Observation groups } & \multirow[b]{3}{*}{ p-value } \\
\hline & \multicolumn{2}{|c|}{ Psoriasis } & \multicolumn{2}{|c|}{ Leprosy } & \multicolumn{2}{|c|}{ Total } & \\
\hline & $\mathrm{n}$ & $\%$ & $\mathrm{n}$ & $\%$ & $\mathrm{n}$ & $\%$ & \\
\hline \multicolumn{8}{|c|}{ Nose pain or irritation } \\
\hline Yes & 4 & 25 & 4 & 25 & 8 & 25 & \multirow[t]{2}{*}{$1.000 *$} \\
\hline No & 12 & 75 & 12 & 75 & 24 & 75 & \\
\hline \multicolumn{8}{|l|}{ Epistaxis } \\
\hline Yes & - & - & 2 & 12.5 & 2 & 6.2 & \multirow[t]{2}{*}{$0.484 *$} \\
\hline No & 16 & 100 & 14 & 87.5 & 30 & 93.8 & \\
\hline \multicolumn{8}{|c|}{ Foreign body sensation in the nose } \\
\hline Yes & - & - & 3 & 18.8 & 3 & 9.4 & \multirow[t]{2}{*}{$0.226^{*}$} \\
\hline Não & 16 & 100 & 13 & 81.2 & 29 & 90.6 & \\
\hline \multicolumn{8}{|c|}{ Olfactory alteration } \\
\hline yes & - & - & 2 & 12.5 & 2 & 6.2 & \multirow[t]{2}{*}{$0.484 *$} \\
\hline Não & 16 & 100 & 14 & 87.5 & 30 & 93.8 & \\
\hline \multicolumn{8}{|c|}{ Rhinorrhea } \\
\hline Yes & 4 & 25 & 3 & 18.8 & 7 & 21.9 & \multirow[t]{2}{*}{$1.000^{*}$} \\
\hline No & 12 & 75 & 13 & 81.2 & 25 & 78.1 & \\
\hline \multicolumn{8}{|c|}{ Another otorhinolaryngological disease } \\
\hline Yes & - & - & 1 & 6.2 & 1 & 3.1 & \multirow[t]{2}{*}{$1.000 *$} \\
\hline No & 16 & 100 & 15 & 93.8 & 31 & 96.9 & \\
\hline \multicolumn{8}{|c|}{ Nasal mucosa } \\
\hline Normal & 13 & 81.2 & 9 & 56.2 & 22 & 68.8 & \multirow[t]{2}{*}{$0.252 *$} \\
\hline Altered & 3 & 18.8 & 7 & 43.8 & 10 & 31.2 & \\
\hline Total & 16 & 100 & 16 & 100 & 32 & 100 & ---.- \\
\hline
\end{tabular}

*Fisher's Exact Test 
Table 3: Operational classification of leprosy according to variables of otorhinolaryngological symptomatology

\begin{tabular}{|c|c|c|c|c|c|c|c|}
\hline \multirow[b]{3}{*}{ Varaibles } & \multicolumn{6}{|c|}{ Operational classification } & \multirow[b]{3}{*}{$\mathrm{p}$-value } \\
\hline & \multicolumn{2}{|c|}{ Paucibacillary } & \multicolumn{2}{|c|}{ Multibacillary } & \multicolumn{2}{|c|}{ Total } & \\
\hline & $\mathrm{n}$ & $\%$ & $\mathrm{n}$ & $\%$ & $\mathrm{n}$ & $\%$ & \\
\hline \multicolumn{8}{|c|}{ Nose pain or irritation } \\
\hline Yes & 1 & 12.5 & 3 & 37.5 & 4 & 25 & $0.569^{*}$ \\
\hline No & 7 & 87.5 & 5 & 62.5 & 12 & 75 & \\
\hline \multicolumn{8}{|l|}{ Epistaxis } \\
\hline Yes & - & - & 2 & 25 & 2 & 12.5 & $0.467 *$ \\
\hline No & 8 & 100 & 6 & 75 & 14 & 87.5 & \\
\hline \multicolumn{8}{|c|}{ Foreign bod sensation in the nose } \\
\hline Yes & - & - & 3 & 37.5 & 3 & 18.8 & $0.200 *$ \\
\hline No & 8 & 100 & 5 & 62.5 & 13 & 81.2 & \\
\hline \multicolumn{8}{|c|}{ Olfactory alteration } \\
\hline Yes & 1 & 12.5 & 1 & 12.5 & 2 & 12.5 & $1.000^{*}$ \\
\hline No & 7 & 87.5 & 7 & 87.5 & 14 & 87.5 & \\
\hline \multicolumn{8}{|l|}{ Rhinorrhea } \\
\hline Yes & 1 & 12.5 & 2 & 25 & 3 & 18.8 & $1.000 *$ \\
\hline No & 7 & 87.5 & 6 & 75 & 13 & 81.2 & \\
\hline \multicolumn{8}{|c|}{ Another Otorhinolaryngological disease } \\
\hline Yes & - & - & 1 & 12.5 & 1 & 6.2 & $1.000 *$ \\
\hline No & 8 & 100 & 7 & 87.5 & 15 & 93.8 & \\
\hline \multicolumn{8}{|c|}{ Nasal mucosa } \\
\hline Normal & 7 & 87.5 & 2 & 25 & 9 & 56.2 & $0.0410 *$ \\
\hline Altered & 1 & 12.5 & 6 & 75 & 7 & 43.8 & \\
\hline Total & 8 & 100 & 8 & 100 & 16 & 100 & ----- \\
\hline
\end{tabular}

*Fisher's Exact Test

Table 4: Operational classification of leprosy according to variables characterizing leprosy reaction

\begin{tabular}{|c|c|c|c|c|c|c|c|}
\hline \multirow[b]{3}{*}{ Variables } & \multicolumn{6}{|c|}{ Operational classification } & \multirow[b]{3}{*}{ p-value } \\
\hline & \multicolumn{2}{|c|}{ Paucibacillary } & \multicolumn{2}{|c|}{ Multibacilary } & \multicolumn{2}{|c|}{ Total } & \\
\hline & $\mathrm{n}$ & $\%$ & $\mathrm{n}$ & $\%$ & $\mathrm{n}$ & $\%$ & \\
\hline \multicolumn{8}{|l|}{ Leprosy reaction } \\
\hline Yes & 1 & 12.5 & 6 & 75.0 & 7 & 43.8 & $0.041 *$ \\
\hline No & 7 & 87.5 & 2 & 25.0 & 9 & 56.2 & \\
\hline \multicolumn{8}{|c|}{ Type of leprosy reaction } \\
\hline Type I & 1 & 12.5 & 3 & 37.5 & 4 & 25.0 & $0.102^{\#}$ \\
\hline Type II & - & 0.0 & 2 & 25.0 & 2 & 12.5 & \\
\hline No information & 7 & 87.5 & 3 & 37.5 & 10 & 62.5 & \\
\hline \multicolumn{8}{|c|}{ Treatment to leprosy reaction } \\
\hline Yes & 1 & 12.5 & 5 & 62.5 & 6 & 37.5 & $0.062^{\#}$ \\
\hline No & - & 0.0 & 1 & 12.5 & 1 & 6.2 & \\
\hline No information & 7 & 87.5 & 2 & 25.0 & 9 & 56.3 & \\
\hline \multicolumn{8}{|l|}{ Nasal mucosa } \\
\hline Normal & 7 & 87.5 & 2 & 25.0 & 9 & 56.2 & $0.041 *$ \\
\hline Altered & 1 & 12.5 & 6 & 75.0 & 7 & 43.8 & \\
\hline Total & 8 & 100.0 & 8 & 100.0 & 16 & 100.0 & --- \\
\hline
\end{tabular}


Carla Andrea Avelar Pires et al. / American Journal of Infectious Diseases 2019, 15 (2): 53.61 DOI: 10.3844/ajidsp.2019.53.61

Table 5: Alteration of Nasal Mucosa according to variables of demographic characterization

\begin{tabular}{|c|c|c|c|c|c|c|c|}
\hline \multirow[b]{3}{*}{ Variables } & \multicolumn{7}{|c|}{ Nasal mucosa } \\
\hline & \multicolumn{2}{|c|}{ Normal } & \multicolumn{2}{|c|}{ Altered } & \multicolumn{2}{|c|}{ Total } & \multirow[b]{2}{*}{ p-value } \\
\hline & $\mathrm{n}$ & $\%$ & $\mathrm{n}$ & $\%$ & $\mathrm{n}$ & $\%$ & \\
\hline \multicolumn{8}{|l|}{ Groups } \\
\hline Psoriasis & 13 & 59.1 & 3 & 30 & 16 & 50 & \multirow{3}{*}{$0.153 *$} \\
\hline leprosy & 9 & 40.9 & 7 & 70 & 16 & 50 & \\
\hline \multicolumn{7}{|l|}{ Gender } & \\
\hline Female & 12 & 54.5 & 1 & 10 & 13 & 40.6 & \multirow[t]{2}{*}{$0.024 *$} \\
\hline Male & 10 & 45.5 & 9 & 90 & 19 & 59.4 & \\
\hline \multicolumn{8}{|c|}{ Age Group (years) } \\
\hline$\leq 30$ & 2 & 9.1 & 3 & 30 & 5 & 15.6 & \multirow{4}{*}{$0.442^{\#}$} \\
\hline$\overline{3} 1$ to 45 & 5 & 22.7 & 3 & 30 & 8 & 25 & \\
\hline 46 to 60 & 10 & 45.5 & 3 & 30 & 13 & 40.6 & \\
\hline$>60$ & 5 & 22.7 & 1 & 10 & 6 & 18.8 & \\
\hline Total & 22 & 100.0 & 10 & 100.0 & 32 & 100.0 & -.---. \\
\hline
\end{tabular}

*Fisher's Exact Tes. ${ }^{*}$ G Test

Table 6: Alteration of Nasal Mucosa according to variables of otorhinolaryngological symptomatology

\begin{tabular}{|c|c|c|c|c|c|c|c|}
\hline \multirow[b]{3}{*}{ Variables } & \multicolumn{6}{|c|}{ Nasal mucosa } & \multirow[b]{3}{*}{ p-value } \\
\hline & \multicolumn{2}{|c|}{ Normal } & \multicolumn{2}{|c|}{ Altered } & \multicolumn{2}{|c|}{ Total } & \\
\hline & $\mathrm{n}$ & $\%$ & $\mathrm{n}$ & $\%$ & $\mathrm{n}$ & $\%$ & \\
\hline \multicolumn{8}{|c|}{ Nose pain or irritation } \\
\hline Yes & 5 & 22.7 & 3 & 30 & 8 & 25 & \multirow[t]{2}{*}{$0.681^{*}$} \\
\hline No & 17 & 77.3 & 7 & 70 & 24 & 75 & \\
\hline \multicolumn{8}{|l|}{ Epistaxis } \\
\hline Yes & - & - & 2 & 20 & 2 & 6.2 & \multirow[t]{2}{*}{$0.091 *$} \\
\hline No & 22 & 100 & 8 & 80 & 30 & 93.8 & \\
\hline \multicolumn{8}{|c|}{ Foreign body sensation in the nose } \\
\hline Yes & 1 & 4.5 & 2 & 20 & 3 & 9.4 & \multirow[t]{2}{*}{$0.224 *$} \\
\hline No & 21 & 95.5 & 8 & 80 & 29 & 90.6 & \\
\hline \multicolumn{8}{|c|}{ Olfactory alteration } \\
\hline Yes & 1 & 4.5 & 1 & 10 & 2 & 6.2 & \multirow{2}{*}{$1.000 *$} \\
\hline No & 21 & 95.5 & 9 & 90 & 30 & 93.8 & \\
\hline \multicolumn{8}{|c|}{ Rhinorrhea } \\
\hline Yes & 4 & 18.2 & 3 & 30 & 7 & 21.9 & \multirow[t]{2}{*}{$0.648^{*}$} \\
\hline No & 18 & 81.8 & 7 & 70 & 25 & 78.1 & \\
\hline \multicolumn{8}{|c|}{ Another Otorhinolaryngological disease } \\
\hline Yes & 1 & 4.5 & - & - & 1 & 3.1 & \multirow[t]{3}{*}{$1.000 *$} \\
\hline No & 21 & 95.5 & 10 & 100 & 31 & 96.9 & \\
\hline Total & 22 & 100.0 & 10 & 100.0 & 32 & 100.0 & \\
\hline
\end{tabular}

* Fisher's Exact Test

Table 7: Operational classification of leprosy according to results of endoscopic examination

\begin{tabular}{|c|c|c|c|c|c|c|c|}
\hline \multirow[b]{3}{*}{ Endoscopic examination } & \multicolumn{6}{|c|}{ Operational classification } & \multirow[b]{3}{*}{ p-value } \\
\hline & \multicolumn{2}{|c|}{ Paucibacillary } & \multicolumn{2}{|c|}{ Multibacillary } & \multicolumn{2}{|c|}{ Total } & \\
\hline & $\mathrm{n}$ & $\%$ & $\mathrm{n}$ & $\%$ & $\mathrm{n}$ & $\%$ & \\
\hline Nasal mucosa & & & & & & & \multirow{5}{*}{$0.040^{\#}$} \\
\hline Altered by leprosy & 1 & 12.5 & 4 & 50.0 & 5 & 31.2 & \\
\hline Altered by another reason & - & - & 2 & 25.0 & 2 & 12.5 & \\
\hline No alteration & 7 & 87.5 & 2 & 25.0 & 9 & 56.3 & \\
\hline Infiltration & & & & & & & \\
\hline Present & 1 & 12.5 & 3 & 37.5 & 4 & 25.0 & \multirow{2}{*}{$0.569^{*}$} \\
\hline Absent & 7 & 87.5 & 5 & 62.5 & 12 & 75.0 & \\
\hline Leproma & & & & & & & \multirow{3}{*}{$0.467^{\#}$} \\
\hline Present & - & - & 2 & 25.0 & 2 & 12.5 & \\
\hline Absent & 8 & 100.0 & 6 & 75.0 & 14 & 87.5 & \\
\hline Hematic crust & & & & & & & \multirow[t]{4}{*}{$0.467^{\#}$} \\
\hline Present & - & - & 2 & 25.0 & 2 & 12.5 & \\
\hline Absent & 8 & 100.0 & 6 & 75.0 & 14 & 87.5 & \\
\hline Total & 8 & 100.0 & 8 & 100.0 & 16 & 100.0 & \\
\hline
\end{tabular}

* Fisher's Exact Test. ${ }^{\text {\# G Test }}$ 
Table 8: Characteristics of the endoscopic examination of the nasal cavity of Fossa and Cavum according to observation groups

\begin{tabular}{|c|c|c|c|c|c|c|c|}
\hline \multirow[b]{3}{*}{ Caracterization } & \multicolumn{7}{|c|}{ Observation group } \\
\hline & \multicolumn{2}{|c|}{ Leprosy } & \multicolumn{2}{|c|}{ Psoriasis } & \multicolumn{2}{|c|}{ Total } & \multirow[b]{2}{*}{ p-value } \\
\hline & $\mathrm{n}$ & $\%$ & $\mathrm{n}$ & $\%$ & $\mathrm{n}$ & $\%$ & \\
\hline \multicolumn{8}{|l|}{ INFERIOR MEATUS } \\
\hline Unobstructed & 13 & 81.2 & 16 & 100 & 29 & 90.6 & $0.3620^{\#}$ \\
\hline Mucoid secretion & 1 & 6.2 & - & - & 1 & 3.1 & \\
\hline Catarrhal secretion & 1 & 6.2 & - & - & 1 & 3.1 & \\
\hline \multicolumn{8}{|l|}{ INFERIOR TURBINATE } \\
\hline Increased & 8 & 50.0 & 4 & 25 & 12 & 37.5 & $0.2720 \#$ \\
\hline Pale & 7 & 43.8 & 10 & 62.5 & 17 & 53.1 & \\
\hline High-coloured & 2 & 12.5 & - & - & 2 & 6.2 & \\
\hline Hummocky & 4 & 25.0 & 5 & 31.2 & 9 & 28.1 & \\
\hline Normal & 7 & 43.8 & 13 & 81.2 & 20 & 62.5 & \\
\hline \multicolumn{8}{|l|}{ MIDDLE MEATUS } \\
\hline Unobstructed & 14 & 87.5 & 16 & 100 & 30 & 93.8 & 1.0000\# \\
\hline Mucoid secretion & 3 & 18.8 & - & - & 3 & 9.4 & \\
\hline Catarrhal secretion & - & - & - & - & - & - & \\
\hline \multicolumn{8}{|l|}{ MIDDLE TURBINATE } \\
\hline Increased & 8 & 50.0 & 5 & 31.2 & 13 & 40.6 & 0.4909\# \\
\hline Pale & 7 & 43.8 & 8 & 50 & 15 & 46.9 & \\
\hline High-coloured & 1 & 6.2 & - & - & 1 & 3.1 & \\
\hline Hummocky & 1 & 6.2 & - & - & 1 & 3.1 & \\
\hline Normal & 8 & 50.0 & 12 & 75 & 20 & 62.5 & \\
\hline \multicolumn{8}{|l|}{ NASAL SEPTUM } \\
\hline High septal deviation & 9 & 56.2 & 11 & 68.8 & 20 & 62.5 & $1.0000 \#$ \\
\hline Anterior septal deviation & 3 & 18.8 & 2 & 12.5 & 5 & 15.6 & \\
\hline Inferior septal crest & 7 & 43.8 & 9 & 56.2 & 16 & 50.0 & \\
\hline Tortuous & 1 & 6.2 & 1 & 6.2 & 2 & 6.2 & \\
\hline Centered & 6 & 37.5 & 6 & 37.5 & 12 & 37.5 & \\
\hline Perforated & - & - & - & - & - & - & \\
\hline \multicolumn{8}{|l|}{ CAVUM } \\
\hline Unobstructed & 11 & 68.8 & 15 & 93.8 & 26 & 81.2 & $1.0000 \#$ \\
\hline Mucoid secretion & 2 & 12.5 & - & - & 2 & 6.2 & \\
\hline Catarrhal secretion & - & - & - & - & - & - & \\
\hline High-coloured & 1 & 6.2 & - & - & 1 & 3.1 & \\
\hline
\end{tabular}

\#G Test

\section{Discussion}

The present study shows a high prevalence of mucosal symptoms in leprosy subjects. The principal nasal mucosal symptoms in leprosy patients are obstruction and epistaxis (Sun et al., 2018). However, in our research, patients mainly complained of nasal irritation and pain. We considered patient reports complaining of an "obstruction" within the nose as equivalent to reports of the sensation of a foreign body present in the nose. This symptom only occurred in the multibacillary patient group and, in this case, could indicate a more severe presentation of the disease. A higher frequency of nasal symptoms was reported in multibacillary cases. This data supports related research that suggests these symptoms can occur prior to the appearance of skin lesions (Martins et al., 2005).

Leprosy reactions can occur before or, more frequently, during or after treatment. The duration and number of these mucosal reactions often depends on the clinical presentation. In our analysis, almost half of the leprosy sample had a reaction. This observation does not take in to account reactions produced after treatment, since our investigation only involved patients undergoing polychemotherapy. Multibacillary patients can develop both types of leprosy reactions, either separately or simultaneously. On the other hand, paucibacillary patients do not have Type II reaction and, therefore, are less exposed to systemic complications. Considering that all the leprosy patients presenting changes in nasal mucosa showed some reaction, the clinical surveillance of this specific group was reinforced, in order to avoid further possible otorhinolaryngological complications.

Leprosy compromises the nasal mucosa, producing typical and individualized lesions of leprous rhinitis, including infiltration, lepromas, perforation, ulcerations and crust formation. However, other observations not exclusive to leprous rhinitis, such as discoloration or 
paleness of the mucosa, congestion, ectasias, vasculitis, atrophy, dryness and presence of blood, can also present in other nasal disorders (Yang et al., 2014). To establish a positive diagnosis of leprosy, bacterioscopy and, especially, mucosal histopathology is required, using precise perivascular and neural infiltration to confirm the etiology (Oliveira and Diniz, 2016). It was not possible to conduct bacterioscopy and mucosal histopathology in our research. We considered typical leprosy lesions as leprosy-specific, for those identified within our study group. Any other lesions observed were considered as not exclusive to leprosy and were classified as nonspecific changes(Martins et al., 2005).

Regarding the endoscopic examination, the only statistical association between the operational classifications of leprosy patients was the alteration in the nasal mucosa. The change caused specifically by leprosy was significantly more frequent in multibacillary patients. Two individuals showed non-specific changes, which could have been attributable to leprosy if they had been subjected to diagnostic confirmation through either bacterioscopy or histopathology. Despite the observed link between each specific alteration in the multibacillary group, there were no significant differences, probably due to the small sample size.

Some authors assert that no lesions occur in the nasal mucosa of patients with the tuberculoid or borderline tuberculoid form of leprosy (Silva et al., 2008) classified as paucibacillary. However, even in our small sample group, there was one patient classified as presenting with tuberculoid leprosy who also presented with a specific leprosy lesion (infiltration) in the mucosa. We also observed that independent of the clinical presentation, mucosal lesions were present despite the absence of symptoms and throughout all stages of the disease.

We worked with three classifications of severity, namely early, intermediate and advanced. In the early classification group, we noted infiltration of the mucosa and abnormal dryness. In the intermediary classification group, the infiltration had increased, causing nasal obstruction, leading to increased nasal secretion and crust formation. Finally, in the advanced classification group, ulcer and secondary infection were observed in addition to a decreased perichondral blood supply. At an advanced stage, perforation of the cartilaginous nasal septum is a potential complication causing changes in sensation and olfactory disruption. Damage to the nasal septum can cause saddle-nose deformity (Silva et al., 2008). In our sample, we noted the presence of early and intermediary changes, but no advanced nasal complications were identified. This finding suggests an improvement in early detection rates in diagnosing patients with leprosy. Early intervention and treatment, in addition to education on simple self-care strategies manageable by patients, may be attributing to a reduction in severe complications and physical changes to the nose.
Other study says that nasal manifestations in leprosy typically develop in 3 stages. The first stage is characterized by a thickening of the mucosa, which appears dry because of the damage of the parasympathetic secretory nerve. The second stage has a characteristic mucosal infiltration. Patients in this stage complain of nasal obstruction, mucopurulent rhinorrhea and epistaxis. The third stage of the disease is a deformity phase (Kim et al., 2015).

The most affected nasal structures are the septum, the nasal conchae and the anterior nasal spine with mucosal coating bilaterally (Silva et al., 2008). In our study, the septum showed the highest number of changes, particularly high septum deviation. No cases of perforation, a particularly stigmatizing characteristic of the disease, were observed.

The higher prevalence of leprosy in men as compared to women may be associated with a wider range of close physical contacts, in association with less attention to self-protective behavior that aims to maintain good physical health (Gashignard et al., 2016; Monteiro et al., 2017). The involvement of this disease throughout the economically active population explains the higher inter-human contact in this population (Barbosa et al., 2014).

The majority of patients lived within the metropolitan region, where there is a higher population density in the capital city areas as compared to other regions, permitting improved access to the dermatology service. Over several decades, awareness has grown of the impact of urbanization on patients with leprosy. Population density and socioeconomic vulnerability serve to increase the risks of identifying and containing leprosy within the urban population (Barbosa et al., 2014).

The levels of education obtained within the leprosy group were consistent with other research carried out in Brazil, which identified limited educational qualifications as a significant characteristic of leprosy patients (Kerr-Pontes et al., 2006). In comparison to the control group, most of the patients had obtained a higher level of education. This characteristic is partially attributable to precarious socioeconomic conditions, resulting in a diminished understanding of this condition and of the intended prescribed treatment pathway. A delay in seeking assistance or abandoning prescribed treatment due to a lack of an appropriate knowledge of the disease has been noted.

All our patients were educated in nasal self-care procedures such as nasal cleansing, lubrication, crust removal, care with hyper-secretion and prevention of traumatizing lesions developing in the mucosa.

Finally, our study suggests that in view of important nasal mucosal changes in leprosy patients compared to controls, it is important to carefully examine this aspect of these patients. 


\section{Acknowledgement}

To the employees of the Laboratory of Sanitary Dermatology and the University Hospital Bettina Ferro de Souza.

\section{Author's Contributions}

Carla Andrea Avelar Pires: Took part in conception, design and revision of the study.

Eline Pinheiro Weba Costa: Responsible for acquisition of data.

Marcus Vinicius Duarte Costa: Responsible for acquisition of data.

Adriana Kamilly Leitão Pitman Machado: Responsible for acquisition of data.

Aline de Lima Dias: Drafted the manuscript.

Gabriela Athayde Amin: Drafted the manuscript.

Manuela Nascimento de Lemos: Revised the manuscript critically.

Alison Ramos da Silva: Drafted the manuscript.

Marcos Antonio Neves Noronha: Revised the manuscript critically.

Marilia Brasil Xavier: Took part in conception, design and revision of the study.

All persons who meet authorship criteria are listed as authors, and all authors certify that they have participated sufficiently in the work to take public responsibility for the content, including participation in the concept, design, analysis, writing, or revision of the manuscript. CAAP and EPWC took part in conception and design of study. MVDC, AKLPM and ALD were responsible for acquisition of data, while $\mathrm{MNL}$ and MANN have done the analysis and interpretation of data. GAA, ARS and MBX have drafted the manuscript together. All authors have revised the manuscript critically and approved the version to be published.

\section{Ethics}

This study was developed in accordance with the ethical standards of the responsible committee on human experimentation (institutional and national) and with the Helsinki Declaration of 1975, as revised in 2008. This study was approved by our local ethics committee.

\section{References}

Barbosa, D.R.M., M.G. Almeida and A.G. Santos, 2014. Características epidemiológicas e espaciais da hanseníase no Estado do Maranhão, Brasil, 20012012. Medicina (Ribeirão Preto), 47: 347-56. DOI: 10.11606/issn.2176-7262.v47i4p347-356
Budel, A.R., A.R. Raymundo, C.F. Costa, C. Gerhardt and L.E. Pedri, 2011. Perfil dos pacientes acometidos pela hanseníase atendidos no Ambulatório de Dermatologia do Hospital Evangélico de Curitiba. An. Bras. Dermatol., 86: 942-6. DOI: 10.1590/s0365-05962011000500012

Gashignard, J., A.V. Grant, N.V. Thuc, M. Orlova and A. Cobat et al., 2016. Pauci- and multibacillary leprosy: Two distinct, genetically neglected diseases. PLoS Negl. Trop. Dis., 10: e0004345e0004345. DOI: 10.1371/journal.pntd.0004345

Kerr-Pontes, L.R.S., M.L Barreto, C.M. Evangelista, L.C. Rodrigues and J. Heukelbach et al., 2006. Socioeconomic, environmental and behavioural risk factors for leprosy in North-east Brazil: results of a case-control study. Int. J. Epidemiol., 27: 1-7. DOI: $10.1093 / \mathrm{ije} / \mathrm{dyl} 072$

Kim, J.S., S.Y. Kwon and J.Y. Shin, 2015. Leproma presenting as a nasal cavity mass. J. Craniofacial Surgery, 26: 694-695. DOI: $10.1097 /$ SCS.0000000000002156

Lastória, J.C. and M.A.M.M. Abreu, 2014. Leprosy: Review of the epidemiological, clinical and etiopathogenic aspects - Part 1. An. Bras. Dermatol., 89: 205-218. DOI: $10.1590 / \mathrm{abd} 1806-4841.20142450$

Lopes, G.L., M.G.L. Borges, A.O. Conceição, K.N.M. Batista andG.M.M. de Macedo et al., 2017. Development and evolution of nerve damage in individuals with leprosy during medical treatment, at completion of MDT and after release from treatment. Indian J. Lepr., 89: 29-38.

Martins, A.C.C., J.C. Castro and J.S. Moreira, 2005. Estudo retrospectivo de dez anos em endoscopia das cavidades nasais de pacientes com hanseníase. Rev. Bras. Otorrinolaringol., 71: 609-616. DOI: 10.1590/S0034-72992005000500011

Monteiro, M.J.S.D., G.M. Santos, M.T.S. Barreto, R.V. de Sousa Silva and R.L.R. de Jesus et al., 2017. Perfil epidemiológico de casos de hanseníase em um estado do nordeste brasileiro. Rev. Aten. Saúde., 15: 21-28. DOI: $10.13037 /$ ras.vol15n54.4766

MSB, 2010. Gabinete do Ministro. Portaria no 3.125, de 7 de outubro de 2010. Aprova as diretrizes para vigilância, atenção e controle da hanseníase. Ministério da Saúde do Brasil.

Oliveira, M.B.B. and L.M. Diniz, 2016. Leprosy among children under 15 years of age: literature review. An. Bras. Dermatol., 91: 196-203.

DOI: $10.1590 / \mathrm{abd} 1806-4841.20163661$

Oliveira, D.T., J. Sherlock, E.V. Melo, K.C.V. Rollemberg and T.R.S. da Paixão et al., 2013. Clinical variables associated with leprosy reactions and persistence of physical impairment. Rev. Soc. Bras. Med. Trop., 46: 600-604. DOI: $10.1590 / 0037-8682-0100-2013$ 
Quagliato, R., 1999. Classificação de Lepra - Madri, 1953Critério clínico. Rev. Bras. Leprol., 27: 17-32.

Queiroz, T.A., F.P.B. Carvalho, C.A. Simpson, A.C.L. Fernandes and D.L.D.A. Figueirêdo et al., 2015. Perfil clínico e epidemiológico de pacientes em reação hansênica. Rev. Gaúcha Enferm., 36: 185-191. DOI: 10.1590/1983-1447.2015.esp.57405

Silva, G.M., L.G. Patrocinio, J.A. Patrocinio et al., 2008. Avaliação otorrinolaringológica na hanseníase: Protocolo de um centro de referência. Arq. Int. Otorrinolaringol., 12: 77-81.
Sun, W.H., Y.R. LI and T.Y. Fang, 2018. Leprosy manifesting as nasal obstruction and epistaxis. J. Formos. Med. Assoc. DOI: 10.1016/j.jfma.2018.06.012

Yang, J.J.H., D.F. Mohallem, T.A. Cardoso, C.L.H. Lima Jr and A.J. Tebcherani et al., 2014. Case for diagnosis. Lepromatous leprosy with nasal lesion: Exuberant clinical presentation. An. Bras. Dermatol., 89: 837-838.

DOI: $10.1590 / \mathrm{abd} 1806-4841.20143045$ 